\title{
TCF12/NR4A3 Fusion Gene
}

National Cancer Institute

\section{Source}

National Cancer Institute. TCF12/NR4A3 Fusion Gene. NCI Thesaurus. Code C99401.

A fusion gene that results from a chromosomal translocation $\mathrm{t}(9 ; 15)(\mathrm{q} 22 ; \mathrm{q} 21)$ which fuses exon 4 of the TCF12 gene to the entire coding sequence of the NR4A3 gene. This rearrangement is associated with extraskeletal myxoid chondrosarcoma. 